\title{
12 \\ TALL TALES AND
BORDERLINE CASES
}

Narratives as meaningful contraband

\author{
Mareike Schomerus and Lotje de Vries
}

\section{Introduction}

In the early hours of the morning of 24 May 2013, a group of South Sudanese vigilantes attacked the town of Obo in the Central African Republic (CAR), having covered the distance of $100 \mathrm{~km}$ from the South Sudan/CAR border to Obo on foot. An unprovoked international attack in violation of CAR's sovereignty could be interpreted as an act of aggression under international law. At the least, one would expect subsequent diplomatic frostiness between the two countries. This attack, however, neither achieved the status of an international incident, nor did it lead to repercussions. Instead, what happened is remembered only as narratives narratives about the attack and the motivations that drove a few dozen assailants to march on a foreign town. How events unfolded became subject to wild interpretation and mostly locallyanchored forms of meaning making.

In many ways, interpretations of the attack and its aftermath mirror the three ways in which the border between South Sudan and CAR is marked. First, there is the only official demarcation of this international border: a border stone, positioned in the shrubs of the bushland, shown in Figure 12.1. The boundary marker is neither fixed to the ground and nor very heavy. Two people could lift it, making its reliability as official border demarcation questionable.

Second, there is the border itself, which is marked primarily by its lack of definability: a vast area of bush and forest in which the exact location of the border is subject to speculation, moveable, and exists only in people's minds. Where precisely the border is understood to run on any given day depends less on international boundary negotiations and more on the luck of hunters, who want to believe that they are still on home grounds - rather than having veered off into the neighbouring nation - whenever they manage to catch an antelope that can feed the family in addition to fetching some money on the market.

Third, there are the $10 \mathrm{~km}$ of road that connect the villages of Ri Yubu on the South Sudanese side and Bambouti in CAR. While it is narrow, built by usage rather than road engineering, full of potholes and barely passable after rain, what is called 'Route Nationale 2' on a map of CAR is the sole officially-named road connection between the two countries. Travelling along it is the only option that offers certainty about moving from one country to the next in a linear way. The villages it connects are some way from the next bigger towns; South Sudan's Tambura, a town of about 10.000 people, lies $40 \mathrm{~km}$ east of Ri Yubu, and 600 


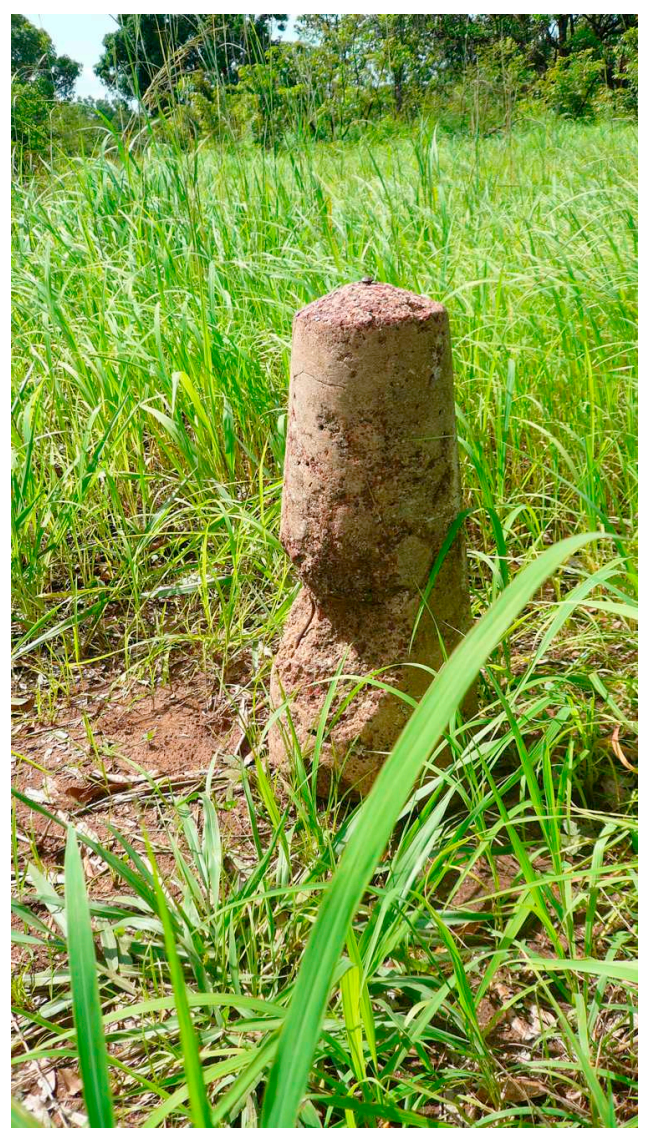

Figure 12.1 The border stone that is the only official demarcation of the border between South Sudan and CAR.

$\mathrm{km}$ from South Sudan's capital Juba. If one were to travel by road, the trip from CAR's Bambouti to the nearest bigger town of Obo (which is about the same size as Tambura) would cover $100 \mathrm{~km}$ westwards through unoccupied countryside. To reach CAR's capital Bangui from here requires another drive of $1200 \mathrm{~km}$.

Three types of border marking, three characteristics that describe this border: an official border point that projects authority and definition, but does not live up to this solid promise; a non-descript area that captures vastness, changeability and ambiguity depending on needs and experiences; and a road that allows defining the border through hindsight as it affirms upon arrival in the next village that the border has been crossed.

These three characteristics interact in different ways with three types of travellers that cross this border: people; goods; and stories. What turns any movement of people and goods into smuggling are legal frameworks, the mode of travel (in this case, often on the back of military trucks that are not subject to search or declaration on either side of the border), and the fact that the travelling goods or people change value as they cross a boundary, usually gaining in market price in comparison to the worth they had on the territory left behind.

This chapter uses a case study of the particular violent incident of crossing this border to unpack how the three characteristics of the border - the official demarcation, the vast and 
ambiguous territory, and the road that passes through and offers certainty through hindsight bestow upon stories, narratives and explanations the characteristics of smuggled goods. Considering how stories and narratives are shaped by crossing a border is new and crucial territory for scholarship on smuggling for two reasons: it highlights the importance of stories and narratives in how people experience and make sense of a situation; and, it embeds emerging research on the power of narratives on people's behaviour within the broader discourse of socially constructed spaces. Borders, the crucial ingredient that smugglers need, are constructed sites of formality as well as informality. Both borders and how they create smuggled goods are great examples of how social construction develops meaning around particular sites or activities. Smuggling is also about the significance that is ascribed to a set of goods or people. Significance or meaning are always created through narratives and stories, so smuggling and meaning are inseparably intertwined.

\section{Contribution to the field: stories as smuggled goods}

The relationship between narratives and smuggling is bidirectional. Narratives help create the possibility of smuggling, while the notion of smuggling can form the characteristics of a narrative. When stories travel across borders, stories, too, can become contraband. These borders, however, are often created in the first place through narratives. When on the road, tales, narratives, accounts or anecdotes display all the characteristics of smuggled goods. Their meaning and importance - in short, what they are worth - can be transformed by having crossed an international border. A narrative shape-shifts as it moves into a different value territory; its meaning and power are bestowed upon it by existing in the borderlands and its ability to traverse these. When stories cross borders, their characteristics and interpretations change along with the narrator's position and how the narrator presents the actors in the story. Meaning and behaviour are altered due to real or imagined constraints or opportunities on either side of the border.

Just as smuggled goods are held back until the market is right, information and rumours may increase or decrease in their valuation and impact depending on when they are deployed. However, what a story is worth will ultimately depend on the context of the border crossed. Even in borderlands where shifting sovereignties play a marginal role in people's lives, how desirable a good or a story is on either side of a border remains separated by the border. The border thus acts as a modifier of the value of the story; it can amplify it. Borders can transform the story, and the story can make the borderlands - just like a border of active smuggling will be shaped by its smugglers. This is how the bidirectional relationship between borders and narratives continues to create the context in which smugglers operate.

For smugglers, information from across the border is critical. It is the basis of their decisions on when to smuggle and at what price to sell their wares. How stories are shaped across borders is thus critical to a livelihood and the power to influence the shape of stories is akin to a smuggler's hard currency. If they are able to transmit a story of scarcity across a border, they are able to increase the value of their goods and their reputation as service deliverers to counter shortages.

There are other shared characteristics between goods and narratives. Just like smuggled objects that are hidden from plain sight or transported on packed motorbikes via backroads in the early morning hours, stories can be whispered, told only after dark, or under embargo. In fact, they are perfect material for smuggling as - unlike goods and people - there are no control mechanisms that could even attempt to control their movement. 
Current scholarship mostly focuses on how borders are shaped by the goods and people that move across it licit and illicit ways; these are interpreted by assessing their intended economic, social or military purpose and how the border changes that purpose (Frahm, 2015, Schomerus et al., 2013, De Vries, 2011, Feyissa, 2010, Newman, 2010, Brunet-Jailly, 2005). The study of smuggling is currently rooted in a material approach, which emphasises perspectives on the value of goods and the value of power that actors derive from being in control of how particular exchanges of goods happen at the border. Such emphasis overlooks the role of borders as important transport carriers for sensemaking. In addition to understanding borders as sociallyproduced demarcations, the imagination of the existence of a border invites us to treat borderlands as a space that shapes narratives and gives meaning to events. For the field of border studies and the attempts to understand the nature, role and impact of smuggling, viewing narratives as tradeable artefacts and part of how people experience the border is a departure from how borders are usually utilised as analytical tools.

Borders are often presented or imagined as intensely securitised and governed spaces. In many cases, however, large swaths of borders are in reality non-existent because they are not governed as a border or marked as such. There can be different reasons for this. People living on either side of the border share the same language, culture and livelihoods, so they rarely experience a border as division. Another reason might be that a border area is just too underpopulated and thus offers little commercial incentive to gain control of the border (Dobler, 2016). In such cases, states may take calculated risks in leaving border management to non-state actors (Schomerus and De Vries, 2014). Even in these seemingly uncontrolled and open spaces, however, stories exist about the meaning of the border - so even where a border does not in fact exist as a governed space, it does exist as a created and actively used concept to support whatever activity is important to the narrator of the border. In addition to circulating stories about the border, simply crossing the border can change a story, an identity, a narrative - or the value of any of these, just like the value of a good changes when it is smuggled across a line.

A deeper understanding of the 'mental landscape' of border residents is currently a blind spot in the study of smuggling. A mental landscape perspective offers a deeper appreciation of the fact that all human sensemaking of everyday life is shaped by

memories and narratives of incidents and history ... Individual emotions, feelings, beliefs, cognitions, as well as the experience of success and disappointment, intermingle with community experiences. The mental landscape also influences decisions and behaviour, highlighting that both are shaped by context. (Schomerus, 2021b, p. 1, see also Amanela et al., 2020b)

People living near borders use them as perspective or interpretative devices to make sense of events they observe and to create narratives of their lives. Stories, ideologies and meaning are shaped by the presence of the border, often creating different interpretations on either side of it. Particularly in contexts of violent conflict, people, stories and ideas can thus take on the hallmarks of 'smuggled' objects. Narratives used to make sense of acts of violence, for instance, can become a story of 'the other side' when moving from one country to the next, particularly if those narratives include people that behave differently depending on if they are on their home turf or on foreign territory.

Perceiving narratives as contraband helps in understanding the implications of the presence of a border to the people living in its vicinity or those operating it. It also offers a helpful reading of national dynamics as perceived from a nation's borderlands. Stories and narratives as smuggled goods shift from seemingly factual accounts to tall tales or anything in between. The 
presence of an international border - however vaguely enforced - adds an additional layer of meaning and complexity to stories that are told on both sides. The social act of remembering produces narratives that explain and shape the present in similar ways to how an economic act of illicit trading shapes markets. They create actions, behaviour, memories - and the next narrative.

\section{When the Arrow Boys crossed the border to march to Obo}

The border between Ri Yubu and Bambouti, between South Sudan and CAR, offers an insightful case study into how the border and the narratives that are carried across it change both a situation and the meaning ascribed to it. From 2008 onwards, this borderland had seen violent attacks by the Ugandan Lord's Resistance Army (LRA), dispersed after the Ugandan forces launched an airstrike on Congolese territory to punish the LRA for failed peacetalks (Schomerus, 2021a, Atkinson et al., 2012). The LRA spread across Western Equatoria State in South Sudan, Haut Mbomou prefecture in the CAR and the Haut Uélé Province in the Democratic Republic of the Congo. Civilians across three countries suffered this insecurity, as well as further negative impacts from the intense army presence of an African Union (AU) Mission with the aim of finding the LRA leader Joseph Kony. The AU mission was manned by the Ugandan People's Defense Forces (UPDF), supported by military advisors from the United States (US), and to a lesser extent the national armies of the three countries (Rigterink and Schomerus, 2017, Rigterink et al., 2014).

The presence of foreign armies offered little protection for civilians; instead it added its own strain to people's perceptions about the LRA and those who said they came to find them (Schomerus, 2012). On the South Sudanese side, the situation led to the formation of an initially dispersed vigilante militia (Schomerus and Tumutegyereize, 2009). These 'Arrow Boys' patrolled the bush along the border, particularly when there were reports of possible movement of armed groups. This meant criss-crossing the unmarked borderline in pursuit of armed rebels, sometimes walking deep -5 or $10 \mathrm{~km}$ - into the CAR.

The Arrow Boys helped US forces with intelligence reports and were sought-after informants by the nearby-stationed UN forces. These international interactions created both a feeling of being informally validated in their work as a protection force, while supporting a growing grievance about the lack of pay or any other form of official recognition (Schomerus and Rigterink, 2015). Years later, in 2020, after many turns of violence, shifting loyalties and betrayal in which the lack of recognition for the Arrow Boys had played a part, one former Arrow Boy was given the governor position for the area (Braak, 2020 (September 7). The broader fall-out from South Sudan's civil war - which started in December 2013, just two years after South Sudan had gained independence - and the politicisation of the Arrow Boys was posing complex challenges to the reintegration of what had then become a collection of armed groups that were posing a danger to civilians and broader peace (McCrone, 2020).

In May 2013, many of these events were still in the future, and the communities affected by insecurity in this border area experienced the Arrow Boys as their deeply-committed protectors. They were seen to provide a service necessary for survival that the national and international armies had failed to deliver. The Arrow Boys carried the narrative of selfless and competent community protection with pride, particularly when they efficiently liaised with international forces and suffered hardship during challenging weeks of patrolling the bush. Across the border, some youth and hunters from Obo tried to replicate the Arrow Boys model by organizing into a local 'auto-defense' that, while offering security to the area's residents, never achieved the widespread legitimacy that the Arrow Boys enjoyed in the early days. 
And then, at 5.45 am on 24 May 2013, everything changed when the group of 40-80 Arrow Boys from South Sudan's Tambura attacked Obo (Ndelet, 2013). The attackers were swiftly arrested by AU soldiers and the local authorities. Twenty-nine of the South Sudanese Arrow Boys were taken to the Obo Gendarmerie; seven of them did not survive the night behind the locked doors of the Gendarmerie.

In the social act of remembering the attack of Tambura's Arrow Boys on Obo, narratives emerged that explained the present and shaped the future in similar ways to how an economic act of illicit trading shapes markets. If we look at narratives as we would at tradable goods that are moving through transport corridors (with the ability to take on the same characteristics that smuggled goods can take on) the shift in value explains the mental landscape of border residents and broader security dynamics. It brings out the role of border crossing as an act of meaningmaking, leaving constraints behind and pursuing opportunities.

\section{Official demarcations}

Why did the Arrow Boys march for days to use their make-shift weapons to attack a town in a foreign country, known to everyone to be full of armed soldiers from three armies? Moreover, why did seven of the assailants die that night?

The various narratives that exist around this event offer vastly differing explanations, yet they all have two things in common. First, the role of the border and how it changes a person's value, constraints, and opportunities as they cross it. Second, that it is impossible to establish and verify one indisputable, ground-truthed explanation. It may well be the case that there are official explanations on both sides of the border. It seems likely, however, that, similar to the movable boundary marker, the exact meaning of such official explanation shifts between the two national authorities and is as unreliable as an official border stone that can be hauled around by two people. Such authoritative narrative might explain what seems like an overly laborious expression of sheer hubris, naivety or criminal energy. This official narrative has not been shared by either South Sudanese or CAR authorities - despite the involvement of governmental and non-governmental actors on either side of this border in the aftermath of the attack.

That aftermath developed at least some resemblance to an official explanation in the ilk of a movable border-stone. A government delegation from Bangui came to talk to the Arrow Boys who were by then referred to as 'the rebels.' CAR authorities decided to skip formal international follow up and to 'pardon everything,' according to the head of the Gendarmerie in Obo. ${ }^{1}$ This move might have been driven by the hope that if CAR did not kick up a fuss about the attack, the South Sudanese authorities would not question further why seven of its citizens died in custody in the CAR. The national chapters of the International Committee of the Red Cross in CAR and South Sudan were charged with the repatriation of both survivors and bodies.

This involvement of national authorities simply suggests the attempt at a narrative of the matter having been dealt with by the authorities, much like the border stone is an attempt of official demarcation. From there on, it gets complicated. Without an official or even logical explanation, the act of sensemaking and situating the story becomes the domain of whoever tells it. Much like smuggled goods, the value of that story and its rationalities differ vastly on both sides of the border, expanding the official demarcation of the story into its vast and ambiguous surrounding territory of bushland, just like the official borderstone sits in undefined territory as seen in Figure 12.2. 


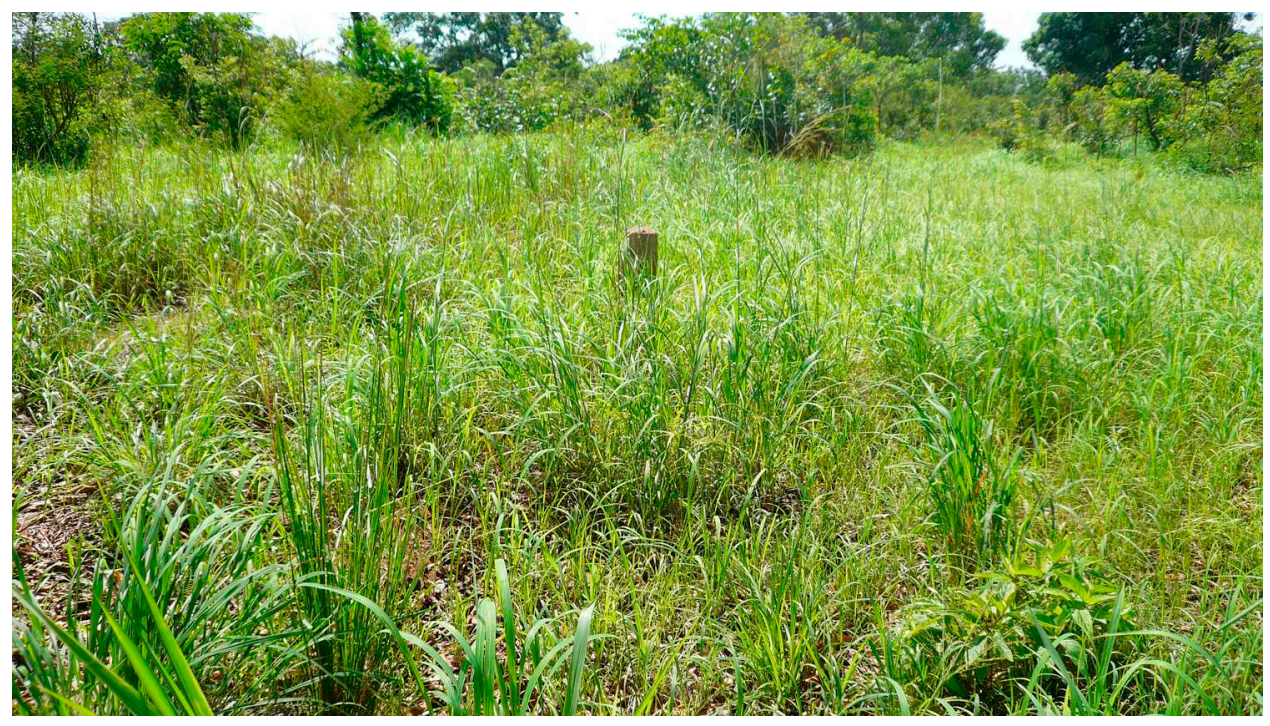

Figure 12.2 The South Sudan/CAR borderstone in the vast bushland.

\section{Vast and ambiguous territory: the many versions of the Arrow Boys attack on Obo}

That the Arrow Boys walked across an invisible line of shifting sovereignties with the purpose to attack a town across the border has been rationalized along the lines of three broad narrative characterisations. These built upon each other and are told in many variations: rewards and jobs; using territorial expansion to behave in ways that bring gain but are not possible at home; or the pursuit of power.

The first narrative seems like the most rational one, but at the same time displays meaningmaking as contraband: the promise of rewards and jobs. Versions of this explanation are that the Arrow Boys were seeking bounty by arresting the leader of the LRA, Joseph Kony. Others claimed that they were guns for hire that had been brought into the interlaced conflict complexities of the South Sudan and the CAR, with possible paymasters being CAR's former president François Bozize, who had been removed from power by the Séléka rebels just a few months prior. Other paymasters on offer were then-Sudanese president Omar al Bashir, South Sudan's president Salva Kiir or vice president Riek Machar respectively (as proxies for their own fight with each other). Some people in South Sudan's Western Equatoria suggested that the Arrow Boys had been hired by South Sudan's notorious National Security to capitalise on the Arrow Boys' skills as spies, offering intel on the situation in the CAR as the country was just becoming embroiled in wide-spread conflict. Proxy wars across borders are common in this region where 'the fluid geographical reach also highlights the blurred boundaries of ideology' (Schomerus, 2021a).

A second set of narratives also looks at material gain, but with a stronger emphasis on how crossing the border increased the possibility and agency of the Arrow Boys' significance and identity. Their violent behaviour and pursuit of material gain would not have been possible within their own communities, so that they had to take their skills gained in serving their communities to get a reward elsewhere for being an Arrow Boy. This narrative suggests that they were fighting their own poverty or even seeking revenge against the various military forces 
who had treated them with disrespect on their own South Sudanese territory or had not renumerated them for their intelligence services. Within Obo, too, the individual motivations of these young men were of lesser concern than the overall motivation of their collective action. Compared to explanations in South Sudan, all narratives circulating across the border were firmly situated in the context of Central African politics, which at that moment in time was in great turmoil.

A third and final variation of narratives in which the border becomes an empowering connector is the explanation that the Arrow Boys were seeking to re-establish forcefully an Azande Kingdom that was to traverse the division of the Azande People created by colonial borders. This kingdom was only possibly with the support of the Azande community around Obo in the CAR; since this support for a South Sudanese-led kingdom was not forthcoming, they sought it by force (Schomerus and Rigterink, 2016, Schomerus, 2014). In Obo, too, some residents championed the idea of an independent Azande kingdom, while others hinted at the ambition to march the $1200 \mathrm{~km}$ towards Bangui to depose the Séléka rebels from their newly gained power. This narrative echoes arguments from scholarship on this part of Africa, that posits that land, identity and citizenship are inseparable (Laudati, 2011). As Pécaut argues, despite the fact that borders are a shared space, establishing ownership of it or across it remains important and is best achieved by narrating such ownership (Pécaut, 2000).

The story about the deaths of seven men in custody created a separate and autonomous collection of rumours. In Obo the stories of what caused their deaths range from lack of oxygen in the police cell, internal fighting among the assailants, to poisoning by people in Obo (some accusing the Muslim community, others the Ugandan army as poisoners). While sensemaking in Obo revolved around community tensions and suspicion and the conflicts in the wider country, the rumours of the causes of death were also smuggled back across the vast and ambiguous territory, into South Sudan in ways that offered meaning to the relatives of those who lost their lives.

\section{The road that offers hindsight}

Narratives are virtuosos of retrofitting; they explain how people - in retrospect - rationalise or even justify their actions and their starting points. Structuration theory has broken down the seemingly bifurcated relationship between structure and agency (Giddens, 1984), while behavioural economists uncovered the decision-making mechanisms that people employ to make quick assessments of a situation (Kahneman and Tversky, 1974). In some sense, the concept of a narrative is itself retrofitted. 'Narrative' is often used as a catch-all term to lump together memory, beliefs, experience, sense-making, social norms or simply the stories that people tell each other about the world in which they live. The personal narrative, following McAdams and McLean, is an internal and evolving life story that integrates an individual's reconstructed past and imagined future to provide life with some degree of unity and purpose (McAdams and McLean, 2013). The collective memory, or the shared pool of knowledge and information among members of a social group creates the emotional 'deep story,' as Hochschild calls it, that binds together a group (Hochschild, 2016, Talarico and Rubin, 2003, Bower et al., 1978).

There does not exist one shared narrative of the border residents - or even amongst Arrow Boys who participated in the ill-fated raid - of why they did what they did. There are some collective semantic memories; these are facts, concepts, and knowledge. Nobody disputes that the raid happened, that the participants used their shared identity as Arrow Boys to attack, or that the Arrow Boys were taken into custody and that seven of them died. This semantic memory mixes with episodic memory - the mosaic of experiences or autobiographical events 
everyone collects to create an individual or communal 'deep story' of meaning (Hochschild, 2016), which covers the possibilities of motivations and reasons outlined above.

Often, research can implicitly assume that people's semantic, episodic and collective memories are a reliable source of information that is stable and consistent - or at least this can be projected too easily in findings. Such research seemingly offers clarity on causality, human behaviour and politics and how these all intersect - without taking into account its own limited framework that produced such clear knowledge (Bliesemann de Guevara and Kostić, 2017). Overconfident findings derived from using people's narratives as hard data has been rightly challenged as continuing to simplify - sometimes with the best of intentions - situations that cannot be simplified (Perera, 2017) and to offer a single catchy image that suggests a linearity that does not exist (Schomerus, forthcoming).

In many ways, stories that become vaguer the more one tries to clarify them have been one of the defining features of our research projects in the borderlands of South Sudan. Much like George Orwell's account of how, as a colonial police officer in British Burma, he shot an elephant, there is never one story to tell about a scene of events. The meaning and interpretations that can be ascribed to the observable facts irrevocably change depending on who narrates and from what perspective. 'A story always sound clear enough at a distance, but the nearer you get to the scene of events the vaguer it becomes,' Orwell observed in 1936 (Orwell, 1968). There is a further complication to an already difficult factual landscape: Almost inevitably, research in contested geographical, political and identity spaces fails to express the ambiguities and changeability of the 'mental landscape,' which is the core of how all events are experienced and interpreted (Schomerus, forthcoming, Trogisch, 2021).

Border studies have alerted us to the power of the border as an interpretative tool. The inconsistencies in sensemaking are amplified by the fluid environment that a border can provide and the power a border has to change the value of something that crosses it. The border offers also a guard rail - within the fluidity it provides, it structures how humans can make sense of their actions on either side of it. The narratives are deeply embedded in the geography of a borderscape that acts less as a physical, and more as a conceptual demarcation line between behaviour at home and behaviour abroad - which in this case means protection of civilians at home and attacks against them abroad.

Different explanatory narratives for the event emerged and the difference can be explained by the exact role assigned to the border in the narrative. When the border is imagined as separating the Arrow Boys from their communities, it gives them permission to pursue material gain with violence in ways they would not employ at home. In other narratives of the event, the border is conceptualised as a connector that allows the Arrow Boys to walk away and across a border in order to reconnect to the bigger politics at their home. In this narrative, the Arrow Boys are said to have gone into CAR to attack Obo as guns for hire for Central African, Sudanese or South Sudanese politicians. The border in this version is akin to a stage, needed for a performance that offers a different meaning on either side of it (Walker et al., 2011). Playing out the narrative of guns for hire for big men could thus offer 'a stage from which to be seen by others,' as Lund argues in his description of 'fruitful misunderstandings' in the performance of research and presenting grievances (Lund, 2014). The narrative of leaving to influence forces back home allows the border to play an identifiable, if complex part. Crossing the border changes the value of the story from the Arrow Boys as an effective civilian protection militia that accepted being overlooked when it comes to receiving official recognition or payment as part of their service to community to a story of a transactional militia seeking rewards. Imagining the border as the gate to proxy wars and engagement means that this narrative combines the social construction of how the border is imagined and the social construction of 
who the Arrow Boys are with the social act of remembering the specific event of the Arrow Boys attack on Obo.

That these changes in meaning happen is perhaps not surprising. Moving from one familiar place to another unfamiliar one changes the mind, as Clark and Chalmers argue while establishing that the environment plays an 'active role ... in driving cognitive processes' (Clark and Chalmers, 1998). In this interpretation, the border is a tool deployed to become part of the cognitive tools of sensemaking - an artifact that, as Heersmink outlines, can be used to create memories (Heersmink, 2018). These memories are shaped by the artifact on offer, which is deployed in a liminal space of change, where one environment is left behind before another is conquered (Thomas, 2020, $17 \mathrm{March}$ ). In that perspective, carrying a narrative across a border and letting it be changed by its environment and social remembering that then creates behaviour and people's actions is not dissimilar to the way the economic act of illicit trading shapes markets on either side of a border.

\section{Narratives as contraband: a future research agenda}

With growing scholarship on the meaning of narratives and the influence of information on people's decision-making and behaviour, the perspective of stories as contraband offers untapped potential for understanding how geographical, social and political boundaries intersect with narratives and actions. Often, the analysis of narratives remains limited to perception surveys, which are used to gauge primarily if a policy or programme is perceived to be working. Integrating a lens that treats narratives as goods that can be altered by identifiable factors offers an additional analytical tool to understand human behaviour.

The current material gaze that guides most scholarship on smuggling is too narrow in how it thinks about value, neglecting too easily that value is a social construct that can only be created through storytelling. There are challenges, however, in looking at narratives too myopically through the smuggling lens, always asking how crossing a border changes them. Analysis of the origin and dynamics of narratives is required also without a look across an imagined or demarcated line to understand how stories of value are created within communities and not just by stepping out of their origin context.

This concern does not dampen the need for interdisciplinary research that combines considerations of smuggling and narratives. As smuggling often happens in intensely securitised spaces, the stories of how, exactly, military presence influences people's lives need to be told. The perspective on people's lives requires a much deeper insight into how narratives are constructed and how they shape behaviour, which calls for tighter interdisciplinary work that combines storytelling with behavioural analysis (Amanela et al., 2020a). This is a challenging field, not just in its data collection and analysis, but also in how crossing the disciplinary boundaries to understand better how stories of boundary crossings influence people's actions is communicated and utilised within academia and policy. A smuggling perspective on stories and a story perspective on smuggling potentially offer great insights once more work is done in this field. What it already offers now is the realisation that - just as with the many versions of the Arrow Boy attack on Obo - there is no single policy to recommend and no single story to tell.

\section{Note}

1 Interview with Commander of the Gendarmerie, March 17, 2015, Obo. 


\section{References}

Amanela, S., Flora Ayee, T., Buell, S., Escande, A., Quinlan, T., Rigterink, A. S., Schomerus, M., Sharp, S. \& Swanson, S. 2020a. Part 2: The Mental Landscape of Post-conflict Life in Northern Uganda: Research on Behaviour and Post-conflict Life in Northern Uganda: The Research Design, London, Secure Livelihoods Research Consortium (SLRC), ODI.

Amanela, S., Flora Ayee, T., Buell, S., Escande, A., Quinlan, T., Rigterink, A. S., Schomerus, M., Sharp, S. \& Swanson, S. 2020b. Parts 1-7: The Mental Landscape of Post-conflict Life in Northern Uganda (report series), London, Secure Livelihoods Research Consortium (SLRC), ODI.

Atkinson, R. R., Lancaster, P., Cakaj, L. \& Lacaille, G. 2012. Do no harm: assessing a military approach to the Lord's Resistance Army. Journal of Eastern African Studies, 6, 371-382.

Bliesemann de Guevara, B. \& Kostić, R. 2017. Knowledge production in/about conflict and intervention: finding 'facts,' telling 'truth.' Journal of Intervention and Statebuilding, 11, 1-20.

Bower, G., Monteiro, K. \& Gilligan, S. 1978. Emotional mood as a context for learning and recall. Journal of Verbal Learning and Verbal Behavior, 17, 573-585.

Braak, B. 2020, September 7. 'Warlord politics' guides peace in South Sudan. Africa at LSE [Online]. Available from: https://blogs.lse.ac.uk/africaatlse/2020/09/07/warlord-politics-guides-peace-insouth-sudan/.

Brunet-Jailly, E. 2005. Theorizing borders: an interdisciplinary perspective. Geopolitics, 10, 633-649.

Clark, A. \& Chalmers, D. 1998. The extended mind. Analysis, 58, 7-19.

De Vries, L. 2011. Négocier l'autorité. Les micro-pratiques étatiques à la frontière du Sud-Soudan et de la République Démocratique du Congo. Politique Africaine, 122, 41-58.

Dobler, G. 2016. The green, the grey and the blue: a typology of cross-border trade in Africa. The Journal of Modern African Studies, 54, 145-169.

Feyeissa, D. 2010. The cultural construction of state borders: the view from Gambella. Journal of Eastern African Studies, 4, 314-330.

Frahm, O. 2015. Making borders and identities in South Sudan. Journal of Contemporary African Studies, $33,1-17$.

Giddens, A. 1984. The Constitution of Society: Outline of the Theory of Structuration, Cambridge, Polity Press.

Heersmink, R. 2018. The narrative self, distributed memory, and evocative objects. Philosophical Studies, $175,1829-1849$.

Hochschild, A. R. 2016. Strangers in Their Own Land: Anger and Mourning on the American Right, New York, NY, New Press.

Kahneman, D. \& Tversky, A. 1974. Judgment under uncertainty: heuristics and biases. Science, 185, 1124-1131.

Laudati, A. 2011. Victims of discourse: Mobilizing narratives of fear and insecurity in post-conflict South Sudan-the case of Jonglei State. African Geographical Review, 30, 15-32.

Lund, C. 2014. The ethics of fruitful misunderstanding. Journal of Research Practice, 10(2).

McAdams, D. \& McLean, K. 2013. Narrative identity. Current Directions in Psychological Science, 22, 233-238.

McCrone, F. 2020. Hollow Promises: The Risks of Military Integration in Western Equatoria, Geneva, Small Arms Survey.

Ndelet, J.-B. 2013. Daily report du 24 Mai 2013-OBO: Tentative d'envahissement de la ville d'Obo par un groupe armée en provenance du Sud-Soudan, UN Obo.

Newman, D. 2010. Territory, compartments and borders: avoiding the trap of the territorial trap. Geopolitics, 15, 773-778.

Orwell, G. 1968. Shooting an Elephant and Other Essays by George Orwell, Ottawa, Distributed Proofreaders Canada.

Pécaut, D. 2000. Configurations of space, time, and subjectivity in a context of terror: the Colombian example. International Journal of Politics, Culture, and Society, 14, 129-150.

Perera, S. 2017. Bermuda triangulation: embracing the messiness of researching in conflict. Journal of Intervention and Statebuilding, 11, 42-57.

Rigterink, A. S., Kenyi, J. J. \& Schomerus, M. 2014. Report of the Justice and Security Research Programme Survey in Western Equatoria State, South Sudan (first round May 2013), London, London School of Economics and Political Science.

Rigterink, A. S. \& Schomerus, M. 2017. The fear factor is a main thing: how radio influences anxiety and political attitudes Journal of Development Studies, 53, 1123-1146. 
Schomerus, M. 2012. They forget what they came for: Uganda's Army in Sudan. Journal of Eastern African Studies, 6, 124-153.

Schomerus, M. 2014. Policy of Government and Policy of Culture: Understanding the Rules of Law in the "Context" of South Sudan's Western Equatoria State. In: Marshall, D. \& Rosenbaum, M. (eds.) The International Rule of Law Movement: A Crisis of Legitimacy and the Way Forward, Cambridge, MA, Harvard Law School Human Rights Programme/Harvard University Press.

Schomerus, M. 2021a. The Lord's Resistance Army: Violence and Peacemaking in Africa, Cambridge, Cambridge University Press.

Schomerus, M. 2021b. The Mental Landscape of Lives in Conflict: Policy Implications, London, Secure Livelihoods Research Consortium (SLRC)/ ODI.

Schomerus, M. (2021). Lives and Violence (Revised), London, I.B.Tauris/Bloomsbury.

Schomerus, M. \& De Vries, L. 2014. Improvising border security: 'A Situation of Security Pluralism' along South Sudan's Borders with the Democratic Republic of Congo. Security Dialogue, 45, 1-16.

Schomerus, M., De Vries, L. \& Vaughan, C. 2013. Introduction: Negotiating borders, defining South Sudan. In: Vaughan, C., Schomerus, M. \& De Vries, L. (eds.) The Borderlands of South Sudan: Authority and identity in contemporary and historical perspectives, New York, Palgrave Macmillan.

Schomerus, M. \& Rigterink, A. 2016. Non-State Security Providers and Political Formation in South Sudan: The Case of Western Equatorias Arrow Boys, Waterloo, Center for Security Governance.

Schomerus, M. \& Rigterink, A. S. 2015. 'And then he switched off the phone': mobile phones, participation and political accountability in South Sudan's Western Equatoria State. Stability: International Journal of Security and Development, 4, 10.

Schomerus, M. \& Tumutegyereize, K. 2009. After Operation Lightning Thunder: Protecting Communities and Building Peace. London, Conciliation Resources.

Talarico, J. M. \& Rubin, D. C. 2003. Confidence, not consistency, characterizes flashbulb memories. Psychological Science, 14, 455-461.

Thomas, E. 2020. Why does travelling change us? The New Statesman, 17 March.

Trogisch, L. 2021. Geographies of fear - The everyday (geo) politics of 'green' violence and militarization in the intended transboundary Virunga Conservation Area. Geoforum, 122, 92-102.

Walker, R., Simmons, C., Aldrich, S., Perz, S., Arima, E. \& Caldas, M. 2011. The Amazonian theater of cruelty. Annals of the Association of American Geographers, 101, 1156-1170. 